\title{
Implementing “4C's” in Teaching Writing in Senior High School
}

\author{
Esti Kurniasih \\ Universitas Negeri Surabaya \\ Surabaya, Indonesia \\ estikurniasih@unesa.ac.id
}

\author{
Ririn Pusparini \\ Universitas Negeri Surabaya \\ Surabaya, Indonesia \\ ririnpusparini@unesa.ac.id
}

\begin{abstract}
C}$ " (i.e. communication skills, collaboration, critical thinking and problem solving, as well as creativity and innovation) are the skills that senior high school graduates should possess in order to achieve the national education goal, i.e. developing students' potentials in order to be a citizen who is well-mannered, skillful, creative, knowledgeable, independent, and responsible for their own action and behavior. To have those skills, the 2013 Curriculum - the curriculum currently applied in Indonesia, offers various interesting and creative learning models that can be applied by teachers in teaching English. Creative learning is a learning process that requires the teachers to motivate and bring up the students creativity during the learning process, using a variety of learning methods and strategies, such as group work (Cooperative Learning), problem solving (Problem Based Learning), Project Based Learning, and so on. Besides, creative learning also requires teachers to be able to stimulate students to bring creativity, both in the context of creative thinking and in the context of creative in doing things. By implementing creative learning models in teaching English, teachers will also automatically apply and integrate "4C's" or 21st Century skills in teaching and learning English.
\end{abstract}

Keywords-4C; $21^{\text {st }}$ century skills, writing; implementation

\section{INTRODUCTION}

$21^{\text {st }}$ century skills or known as " $4 \mathrm{C}$ " are the skills that students should possess in order to achieve the national education goal that is developing students' potentials in order to be a citizen who is well-mannered, skillful, creative, knowledgeable, independent, and responsible for their own action and behaviour. Besides these $21^{\text {st }}$ century skills, every graduate of primary and secondary schools should also have competencies on three domains, they are attitudes, knowledge, and skills. To have graduates who have those competencies and skills, the 2013 Curriculum - the curriculum currently applied in Indonesia, offers various interesting and creative learning models that can be applied by teachers in teaching English. Creative learning is a learning process that requires the teachers to motivate and bring up the students creativity during the learning process, using a variety of learning methods and strategies, such as group work (Cooperative Learning), problem solving (Problem Based Learning), Project Based Learning, and so on. Besides, creative learning also requires teachers to be able to stimulate students to bring creativity, both in the context of creative thinking and in the context of creative in doing things. By implementing creative learning models in teaching English, teachers will also automatically apply and integrate " $4 \mathrm{C}$ 's" or 21 st Century skills in teaching and learning English which cover communication skills, collaboration, critical thinking and problem solving, as well as creativity and innovation.

Based on the background above, the researchers therefore intend to describe the implementation of creative learning models which integrate " $4 \mathrm{C}$ " in teaching writing in senior high school when it is viewed from the skills of students in thinking and acting communicatively, creatively, collaboratively, and critically.

Life in the 21 st century requires students to master a variety of skills, such as communication skills, collaboration, critical thinking and problem solving, creativity and innovation, information and communication technology literacy, contextual learning, and media literacy. All these $21 \mathrm{st}$ century skills can be achieved by updating the quality of learning process. In its application, all of those skills or known as " $4 \mathrm{C}$ " are integrated into learning which is based on the 2013 Curriculum, they are: (1) students are placed as the learning subjects who are actively developing their interests and potentials, constructing their knowledge and skills based on their capacity and level of cognitive development, and contributing to solve real problems that occur in society; (2) as a facilitator, teacher helps students to link their prior knowledge with new information that they will learn, gives them an opportunity to learn in accordance with their learning styles, and encourages them to be responsible for the learning process they do; (3) students should be able to collaborate with their friends who have different cultural backgrounds and values; (4) learning materials should be contextual in order that students can apply their learning outcomes in their daily lives; and (5) learning should facilitate students to be involved in their social environment. Besides integrating those skills into learning which is based on the 2013 Curriculum, implementing creative learning models can be the alternative for applying and integrating " $4 \mathrm{C}$ 's" or 21 st Century skills into learning. Related to creative learning models, numerous interesting and creative learning models are developed, they are project based learning, discovery learning, problem-based learning, cooperative learning, scientific approach, genre based approach, etc. 
Learning model can be defined as a systematic procedure of organizing learning experiences to achieve learning goals. Dahlan (1990) considers learning model as a plan for setting the curriculum, developing the instructional materials and guiding the teachers in delivering the materials. While Trianto (2007:1) defines the learning model as a plan used for guiding the teachers in planning and designing the course. From those definitions, it can be concluded that learning models deal with the ways in which learning environments and instructional experiences can be constructed, sequenced or delivered. Among many kinds of learning models, creative learning models are those which are offered by 2013 Curriculum.

2013 Curriculum is the replacement of the previous curriculum (2006 Curriculum). This curriculum is communicative and competency-based where students can apply various kinds of competencies in their daily life. There are 2 main components in 2013 Curriculum: Core Competencies (Kompetensi Inti/KI) and Basic Competencies (Kompetensi Dasar/KD). Core competence is the level of ability to achieve Graduate Competency Standards that a student must have at each grade level. Core competencies in 2013 Curriculum consist of spiritual manner/attitude, social manner/attitude, knowledge, and skills. While Basic Competence is the minimum ability that must be achieved by students for a certain subject in each educational level. The Basic Competencies of English in senior high school comprise (1) applying the social functions, text structure, and language features of several text types; (2) differentiating the social functions, text structure, and language features of several text types; and (3) interpreting the social functions and language features of songs (KD 3); and also getting the text meaning and constructing/writing a text $(K D 4)$. Related to Writing skill, the text types (genres) and short functional texts taught in senior high school consist of descriptive text, announcement, and recount text (tenth grade); formal invitation, analytical exposition, and personal letter (eleventh grade); and application letter and caption (twelfth grade).

Writing is very important skill to be learned. Through writing, one can inform others, carry out transactions, persuade, infuriate, tell others how he/she feels, learn to shape his or her thoughts and ideas, etc. To produce a good writing, some components of writing should be involved, they are: content, organization, vocabulary, language use, and mechanics (Heaton, 2006:146; Jacobs, et al., 1981). While Gebhard (2000:221) states such components as vocabulary, language use, mechanics, organization, kinds/types of readers, and the goal of writing need to be considered in writing. In addition to writing components, the process of writing also needs to be taken into account. Writing is not a simple activity that could be done simultaneously. Instead, writing is a complex process that requires the writers to process and develop their ideas, arrange them appropriately, use proper punctuation mark, select and employ appropriate word choice (vocabulary) and grammar, until a good final writing product is produced. Brown (1994) states that writing is an activity that involves the process of thinking, drafting, and revising. Another expert, Hammer (cited in Richard \& Renandya,
2002:303) proposes four stages of writing process. Those are planning, drafting, revising and final drafting/editing. Meanwhile, Gebhard (2000:226) and Boas (2011) mention three stages in writing, those are prewriting (planning), drafting (writing draft), and revising. From those experts' opinions and ideas about the process of writing as mentioned above, it can be concluded that writing needs a regular and gradual practice.

\section{METHODS}

Since this paper aims at investigating and describing the implementation of creative learning models which integrate "4C" in teaching writing in senior high school when it is viewed from the skills of students in thinking and acting communicatively, creatively, collaboratively, and critically, descriptive qualitative research is an appropriate design used in this research. The subjects of this study are 30 In-service students of English Education Study Program at Unesa, The data in this study are the results of observation on the implementation of learning activities or process which uses creative learning models that integrate "4C" in teaching writing in senior high school when it is viewed from the skills of students in thinking and acting communicatively, creatively, collaboratively, and critically. To assist the process of data collection, the researchers used observation sheet for analyzing the learning activities/process and scoring rubric on 21 st century skills for analyzing the students skills in communicating, thinking creatively, collaborating, and thinking critically during the learning process of writing in the class. In line with the research instruments used, two techniques of data collection were also occupied in this research, they are observation and documentation techniques. After collecting the data, they were then analyzed qualitatively.

\section{RESULTS AND DISCUSSION}

From the observation result on the implementation of learning processes/activities that use creative learning models which integrate " $4 \mathrm{C}$ " in teaching writing in senior high school when it is viewed from the skills of students in thinking and acting communicatively, creatively, collaboratively, and critically, it was found out that four creative learning models were frequently applied. Those are Scientific Approach (SA), Genre Based Approach (GBA), Project Based Learning (PBL), and Task Based Learning. Whatever the approach or method was applied, the process or learning activities on writing skill in senior high school include pre-activities, whilst activities, and post activities.

The following is the detail result of the observation towards the implementation of learning processes or activities using creative learning models which integrate " $4 \mathrm{C}$ " in teaching writing in senior high school when it is viewed from the skills of students in thinking and acting communicatively, creatively, collaboratively, and critically. 


\section{T3\#, T4\#, T5; T7; and T9\#}

From the result of the observation, T3\#, T4\#, T5\#, T7\#, and T9\# applied learning activities which used Scientific Approach (SA). Scientific Approach is one of the creative learning models that comprises five stages, those are observing (identifying something), questioning (and formulating hypothesis), experimenting/collecting information, associating/analyzing information, and communicating (Ministry of Education and Culture, 2013). Below is the detail implementation of learning process/activities which used Scientific Approach and integrate "4C" in teaching writing in senior high school.

\section{a. Pre-Activities}

In this activity, first, the teacher greeted the students and asked one of the students to lead the pray, then followed by checking the attendance, motivating the students to learn, giving brainstorming activity, and telling the students the topic of the lesson and the learning objectives.

\section{b. Whilst Activities}

In this activity, by using Scientific Approach that covers five stages, namely observing, questioning, experimenting/collecting information, associating/analyzing information, and communicating, the teacher delivered formal invitation materials related to school activities (T3\#), analytical exposition text related to actual issues (T4\#), announcement on school activities (T5\#), personal letter (T7\#), and descriptive text on tourism objects (T9\#), clearly and systematically. The teacher also implemented the concept of learning materials in the daily life; employed active learning; enriched good habits during the learning process; used tools/materials, media and IT; managed the class conductively; used language clearly which was easily understood by students; implemented the process and product assessment, showed empathy and care for students; and had an open attitude towards the students.

Related to $21^{\text {st }}$ century skills or known as " $4 \mathrm{C}$ ", it was found out that those skills were employed and integrated during the implementation of whilst activities. In particular, the students' skills in thinking creatively and critically occurred in questioning stage. Here, students asked some questions they have not understood yet in order to fulfill their curiosity that they get in the previous stage (i.e. observing stage). Their ability to form questions finally can develop their creativity and form their critical mind as well. Besides, teacher can also make a question in order to stimulate students' curiosity so that the students will ask some more questions. Certainly, in this stage, the role of teacher as a facilitator is mostly needed in encouraging or stimulating students to ask

In experimenting stage, the students developed their skills in communicating and collaborating since in this stage the students in group carried out experiments, read other resources besides textbooks, shared the information to the group members, observed objects/events/activity, and interviewed the informants. The information that they got would finally give them new experience and lead them to understand more about the lesson.

Meanwhile in associating stage, the students' skills on critical thinking, problem solving, communication skill, and collaborating were enhanced. Here, the students in group rearranged the jumbled paragraphs into coherent and unified text and developed essays (i.e. formal invitation related to school activities, analytical exposition text related to actual issues, announcement on school activities, personal letter, and descriptive text on tourism objects) based on the given topic/situation/video. In developing essays, the students in group integrated, connected, and analyzed the information they have got in the previous stage (i.e. experimenting stage). They might get new understanding about what they have learnt through relating and analyzing some information or previous data (information) they had collected, while the teacher as the facilitator did confirmation about what students have gotten.

Lastly, in communicating stage the students were required to communicate and perform what they have done in previous stage (i.e. associating stage) verbally, in writing or through the other media. From this activity, the students' skill on communicating was developed.

\section{c. Post Activities}

Before closing the teaching and learning process, both the teacher and the students reviewed the lesson. Besides, they also discussed about some problems and difficulties encountered by the students during the learning process and looked for the solution (doing reflection). At last, the teacher announced the next topic of the learning materials for the upcoming meeting.

\section{T1\# and T2\#}

From the result of the observation, T1\# and T2\# applied learning activities which used Genre Based Approach (GBA).

Genre is primarily recognized by its communicative purpose, which shapes how a text is realized. Genre Based Approach (GBA) consists of four stages, namely Building Knowledge of the Field (BKOF), Modelling of the Text (MOT), Joint Construction of the Text (JCOT), and Independent Construction of the Text (ICOT). Below is the detail implementation of learning process/activities which used Genre Based Approach (GBA) and integrate "4C" in teaching writing in senior high school.

\section{a. Pre-Activities}

In this activity, first, the teacher greeted the students and asked one of the students to lead the pray, then followed by checking the attendance, motivating the students to learn, giving brainstorming activity, and telling the students the topic of the lesson and the learning objectives.

\section{b. Whilst Activities}

In this activity, through Genre Based Approach (GBA) which includes four stages namely Building Knowledge of the Field (BKOF), Modelling of the Text (MOT), Joint 
Construction of the Text (JCOT), and Independent Construction of the Text (ICOT), the teacher delivered recount text related to historical events (TI\#) and announcement on school activities (T2\#) clearly; implemented the concept of learning materials in the daily life; implemented active learning; enriched good habits during the learning process; used tools/materials, media and IT; managed the class conductively; used language clearly and easily understood by students; implemented the process and product assessment, showed empathy and care for students; and had an open attitude towards the students.

Related to $21^{\text {st }}$ century skills or known as " 4 C", it was found out that those skills were employed and integrated during the implementation of whilst activities. In particular, the students' skills in collaborating, communication skill, thinking creatively and critically occurred in Joint Construction of the Text (JCOT) and Independent Construction of the Text (ICOT). In Joint Construction of the Text (JCOT), by working collaboratively the students were assigned to rearrange the jumbled paragraphs of recount text into a good order. The fastest group who did the task correctly would be the winner and given a reward. Another activity that students should do is analyzing the errors in announcement text. Within groups, they had to analyze the errors of language features used in announcement text. Next, they had to rewrite the correct form of that text. Besides those two activities, the students still in the same group were also assigned to make a mind map as the outline of recount text and announcement. Then in Independent Construction of the Text (ICOT) students individually should develop it into a coherent and unified recount and announcement text. Here, students' skills on thinking creatively and critically were developed.

\section{c. Post Activities}

Before closing the teaching and learning process, both the teacher and the students reviewed the lesson. Besides, they also discussed about some difficulties encountered by the students during the learning process and looked for the solution (doing reflection). At last, the teacher announced the next topic of the learning materials for the upcoming meeting.

\section{T6\#}

From the result of the observation, T6\# applied learning activities which used Project Based Learning (PBL). Project Based Learning is a comprehensible instructional model that engages learners in such complex activities as choosing the topic for their project, searching for resources for needed information, organizing those resources, developing the project, combining the contributions of the group, solving the problems, creating the rubric for the assessment, presenting/sharing the project with other groups, obtaining the feedback, and doing group reflection toward the project. Project Based Learning offers many advantages and challenges when it is implemented in the classroom, they are increasing motivation, problem-solving ability, media research skills, collaboration, and resource management skills (Bransford \& Stein, 1993).
As one of the creative learning models, Project Based Learning consists of six stages, they are (1) start with the essential question; (2) design a plan for the project; (3) create a schedule; (4) monitor the students and the progress of the project; (5) assess the outcome; and (6) evaluate the experience. Below is the detail implementation of learning process/activities which used Project Based Learning and integrate " $4 \mathrm{C}$ " in teaching writing in senior high school.

\section{a. Pre-Activities}

In this activity, first, the teacher greeted the students and asked one of the students to lead the pray, then followed by checking the attendance, motivating the students to learn, giving brainstorming activity, and telling the students the topic of the lesson and the learning objectives.

\section{b. Whilst Activities}

In this activity, through Project Based Learning (PBL) which comprises six stages, they are (1) start with the essential question; (2) design a plan for the project; (3) create a schedule; (4) monitor the students and the progress of the project; (5) assess the outcome; and (6) evaluate the experience, the teacher delivered descriptive text related to the famous historical buildings (T6\#) clearly; implemented the concept of learning materials in the daily life; employed active learning; enriched good habits during the learning process; used tools/materials, media and IT; managed the class conductively; used language clearly and easily understood by students; implemented the process and product assessment, showed empathy and care for students; and had an open attitude towards the students.

Related to $21^{\text {st }}$ century skills or known as " $4 \mathrm{C}$ ", it was found out that those skills were employed and integrated during the implementation of whilst activities. In particular, the students' skills in collaborating, communication skill, thinking creatively and critically occurred from the second stage (i.e. design a plan for the project) until the sixth stage (i.e. evaluate the experience). Here, within groups, students discussed about the topic of their project, searched for resources for needed information, organized those resources, developed the project, combined the contributions of the group, solved the problems, created the rubric for the assessment, presented/shared the project with other groups, obtained the feedback, and conducted group reflection toward the project. From what the students did above, it can be clearly seen that they developed their motivation, problem-solving ability, media research skills, collaboration, communication skill, resource management skills, and critical and creative thinking. This is in line with what Bransford and Stein said about skills and competencies that are developed from the implementation of Project Based Learning (Bransford \& Stein, 1993).

\section{c. Post Activities}

Before closing the teaching and learning process, both the teacher and the students reviewed the lesson. Besides, they also discussed about some problems and difficulties 
encountered by the students during the learning process and looked for the solution (doing reflection). At last, the teacher announced the next topic of the learning materials for the upcoming meeting.

\section{T8\#}

From the result of the observation, T8\# applied learning activities which used Task Based Learning. Freeman and Anderson (2011) define Task Based Learning as one of the creative learning models whose goal is facilitating students' language learning by engaging them in a variety of tasks that have a clear outcome. They further stated that Task Based Learning consists of three stages, they are pre-task, task, and post-task. Below is the detail implementation of learning process/activities which used Task Based Learning and integrate "4C" in teaching writing in senior high school.

\section{a. Pre-Activities}

In this activity, first, the teacher greeted the students and asked one of the students to lead the pray, then followed by checking the attendance, motivating the students to learn, giving brainstorming activity, and telling the students the topic of the lesson and the learning objectives.

\section{b. Whilst Activities}

In this activity, through Task Based Learning which comprises three stages, they are pre-task, task, and post-task, the teacher delivered analytical exposition text related to the actual issues (T8\#) clearly; implemented the concept of learning materials in the daily life; employed active learning; enriched good habits during the learning process; used tools/materials, media and IT; managed the class conductively; used language clearly and easily understood by students; implemented the process and product assessment, showed empathy and care for students; and had an open attitude towards the students.

Related to $21^{\text {st }}$ century skills or known as " $4 \mathrm{C}$ ", it was found out that those skills were employed and integrated during the implementation of whilst activities. In particular, the students' skills in collaborating, communication skill, thinking creatively and critically occurred in the Task and Post-task stage. In the Task stage, within groups the students were assigned to rearrange the jumbled paragraphs of analytical exposition text into a correct order. Next, still in the same group the students were also assigned to make an outline and develop it into a coherent and unified analytical exposition text. While in Post-task stage, the students with their own group were asked to present their writing result (i.e. analytical exposition text) in order to get feedback from the other groups and teacher. Besides, there was also question and answer session during this stage. Here, the other groups were allowed to ask questions to the group who was presenting their writing result. This was done in order to give feedback for revision. During the post-task stage the students developed their skills on collaborating, communicating, and critical thinking.

\section{c. Post Activities}

Before closing the teaching and learning process, both the teacher and the students reviewed the lesson. Besides, they also discussed about some problems and difficulties encountered by the students during the learning process and looked for the solution (doing reflection). At last, the teacher announced the next topic of the learning materials for the upcoming meeting.

\section{CONCLUSION}

Based on the results and discussion above, it can finally be concluded that senior high school students had applied and developed the $21^{\text {st }}$ century skills or known as " $4 \mathrm{C}$ " (i.e. the students' skills in thinking and acting communicatively, creatively, collaboratively, and critically) which were frequently employed and integrated with the implementation of whilst writing activities of Scientific Approach (SA), Genre Based Approach (GBA), Project Based Learning (PBL), and Task Based Learning.

\section{REFERENCES}

[1] Boas, V. (2011). Process Writing and the Internet: Blogs and Ning Networks in the Classroom. Retrieved September 29, 2008, from http://English Teaching Forum Journal, Vol. 49 (2) pp. 26-33.

[2] Bransford, J.D. and Stein, B.S. (1993). The Ideal Problem Solver: A Guide for Improving Thinking, Learning, and Creativity. New York: freeman, Ltd.

[3] Brown H. D. (1994). Principles of Language Learning and Teaching. $3^{\text {rd }}$ Edition. Englewood Cliffs, NJ: Prentice Hall Regents.

[4] Dahlan. (1990). Model-model Mengajar. Bandung: Diponegoro.

[5] Freeman, D.L. and Anderson, M. (2011). Techniques and Principles in Language Teaching. Oxford: Oxford University Press.

[6] Gebhard, J.G. (2000). Teaching English as a Foreign or Second Language. Ann Arbor: The University of Michigan Press.

[7] Jacobs, H.L. et al. (1981). Testing ESL Composition: A Practical Approach. Rowley: Newbury House Publishers, Inc.

[8] J.B Heaton. (2006). Writing English Language Tests. London: Longman, Ltd.

[9] Peraturan Menteri Pendidikan dan Kebudayaan (PERMENDIKBUD). (2013). Kurikulum Nasional. Jakarta. Permendikbud.

[10] Peraturan Pemerintah. (2003). Peraturan Pemerintah Nomor 20 Tahun 2003 tentang Sistem Pendidikan Nasional. Jakarta.

[11] Richards, J. C. and W. A. Renandya. (eds.). (2002). Methodology in Language Teaching: An Anthology of Current Practice. Cambridge: Cambridge University.

[12] Trianto. (2007). Model-model Pembelajaran Inovatif Berorientasi Konstruktivistik. Jakarta: Prestasi Pustaka. 